\title{
Risk factors of acute otitis media among children in Mosul
}

\author{
Asma O. Abed Alsalam ${ }^{a}$, Zaid M. Yassen ${ }^{b}$, Marwan F. Buraa ${ }^{c}$ \\ ${ }^{a}$ Arab Board candidate, Scientific Council of Family Medicine, Arab Board for Health Specializations, ${ }^{b}$ Department of Family \\ and Community Medicine, College of Medicine, University of Mosul, ${ }^{\circ}$ Department of ENT, Al Jamhory Teaching Hospital, \\ Mosul, Iraq. Correspondence: Zaid M. Yassen. zaidyassen67@yahoo.com.
}

(Ann Coll Med Mosul 2018; 40 (1): 7-14).

Received: $9^{\text {th }}$ May 2013; Accepted: $13^{\text {th }}$ Nov. 2013.

\section{ABSTRACT}

Context: Acute otitis media (AOM) is the most frequent diagnosis in the children visiting offices. The prolonged and recurrent episodes of AOM may lead to hearing impairment and delayed speech development, which will influence the child's performance at school.

Aim: The aim of this study is to identify the risk factors of acute otitis media in preschool children attending ENT clinics at Al-jamhory Teaching Hospital in Mosul.

Methods: To achieve this aim, a case control study design was adopted. The sample of the present study included 150 children (cases) who have been diagnosed by the responsible ENT specialist according to the otoscopic examination with another 150 children (controls) who were diagnosed not to have AOM. Period of data collection was from $1^{\text {st }}$ of October 2011 to the $1^{\text {st }}$ of April 2012.

Results: The present study showed that the highest frequency of acute otitis media occurred in the age group 1-2 years 39 patients (26\%), and more frequent AOM attacks occurred in males. Clinical presentation among the cases were fever, otalgia, otorrhea, irritability, loss of appetite, vomiting, diminished hearing, and few patients presented with tinnitus and vertigo. The significant risk factors for AOM were day care attendance, bottle feeding for the $1^{\text {st }} 6$ months of life, supine bottle feeding, pacifier use in the second 6 months of life, parental tobacco smoking, preterm baby, and allergy. No association was found between craniofacial anomaly and occurrence of $A O M$ in the present study.

Conclusion: Day care attendance, bottle feeding during the $1^{\text {st }} 6$ months of life, supine bottle feeding, pacifier use in the second 6 months of life, parental tobacco smoking, preterm baby, and allergy were found to be a significant risk factors for AOM among study population.

Recommendation: Additional studies on potential measures to prevent AOM through the reduction of risk factors are needed.

Keywords: Acute otitis media, risk factors, children, Mosul City.

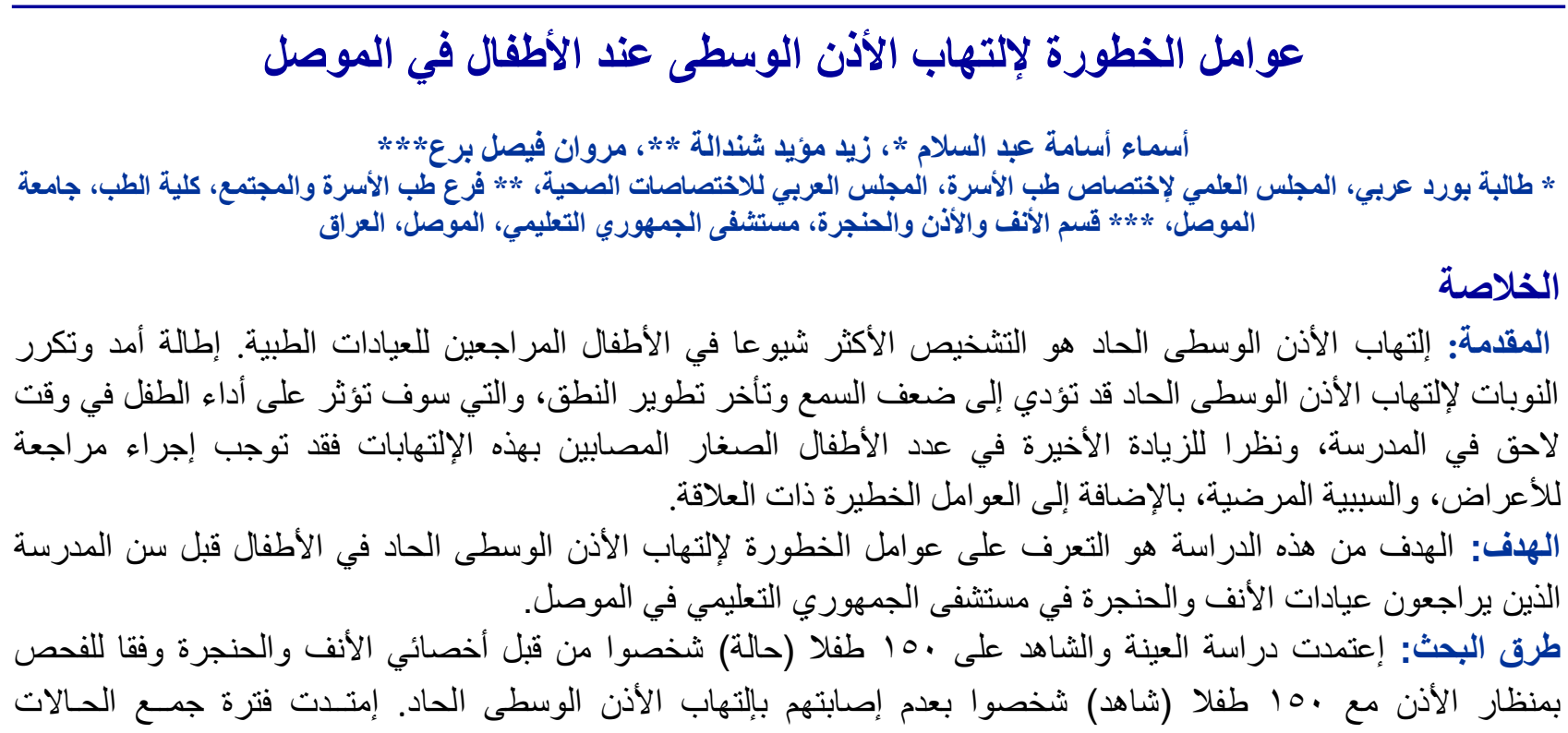




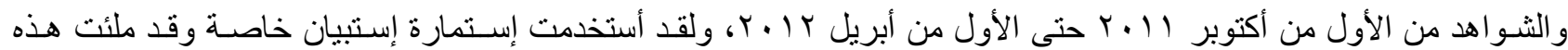

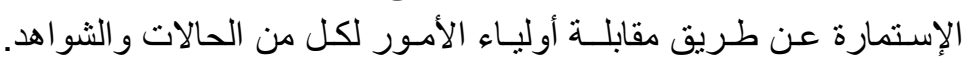

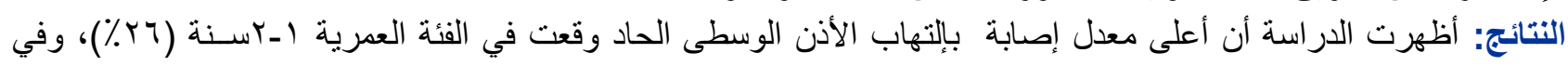

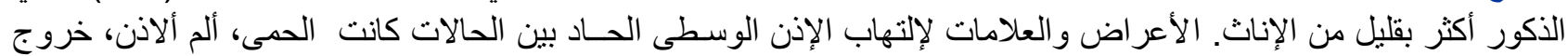

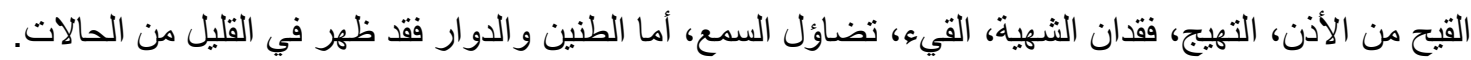

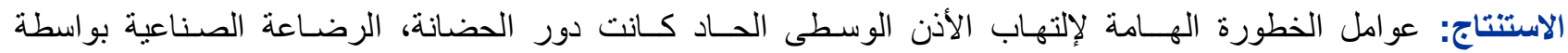

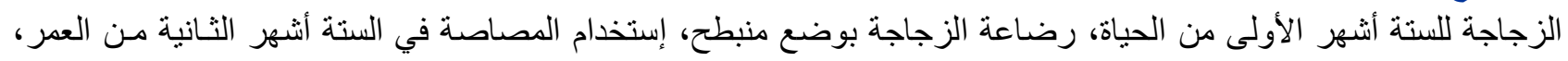

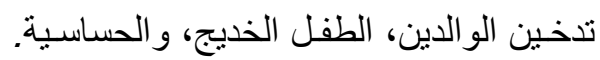
الكلمات المفتاحيه: إلتهاب الأذن الوسطى الطئ الحاد، عوامل الخطورة، الأطفال، مدينة الموصل.

\section{INTRODUCTION}

O titis media is an irritation of the middle ear cleft, without reference to aetiology or pathogenesis. The clinical range may expand from a benign, self-limiting state to a expanded and sometimes complicated illness. Although in industrialised countries serious complications are rare, the burden of acute otitis media (AOM) is large, with impaired quality of life and high direct and indirect socio-economic costs. Otitis media primary described by Hippocrates in $450 \mathrm{BC}$, this illness continues to present one of the more troublesome health troubles of Infancy and childhood. ${ }^{1}$

Acute otitis media is one of the most widespread communicable diseases occurring during childhood. Prolonged and recurrent attacks of AOM may lead to hearing impairment and late speech development, which will influence the child's later performance at school. ${ }^{2}$

The yearly cost of AOM in the United States is an estimated $\$ 5$ billion. $^{3}$

AOM occurring most commonly between the ages of 3 months and 3 years. ${ }^{1}$ By age of 7 years, $93 \%$ of children have had at least one incident of AOM and $75 \%$ have had repeated infections. AOM can occur at any age, $80-90 \%$ of cases occur in children younger than 6 years, and the highest incidence is between 6 months and 24 months of age in the United States. ${ }^{4}$ Males are somewhat more affected than females; of unknown cause. ${ }^{5}$

Morbidity from this illness remains noteworthy, despite numerous use of systemic antibiotics to treat the sickness and its complications. Intratemporal and intracranial complications of $\mathrm{OM}$ are the 2 major types. ${ }^{6}$ Risk factors of AOM are several including: ${ }^{4}$

\section{1- Day Care attendance:}

Contact to other children at home (siblings) or in a day-care surroundings increases the risk of otitis media, with the relative risk being proportionate to the quantity of kids in a setting. ${ }^{7}$

\section{2- Type of Feeding:}

In many studies, breast-feeding has been stated as reducing the risk of ear and pulmonary infections. A two-fold increase in hazard of first episodes of AOM was found in infants completely formula-fed as contrasting to those breast-fed for 6 months. ${ }^{8}$

\section{3- Supine bottle feeding:}

Lying position of the baby during feeding was associated with acute otitis media. Babies with otitis media were 38 times more likely to be fed in lying position than babies without otitis media. ${ }^{9}$

\section{4- Use of Dummies (Pacifiers):}

Studies from Finland have revealed that use of a pacifier is a hazard factor for otitis media. ${ }^{10}$

\section{5- Passive Smoking and Environmental Pollution:}

Meta-analyses confirm the increased incidence of otitis media associated with exposure to passive cigarette smoke. ${ }^{11}$

\section{6- Premature birth:}

Very low birth weight $(<1500 \mathrm{~g})$ or very preterm birth ( $<33$ weeks of gestation) increases the risk of otitis media. $^{12}$

\section{7- Male gender:}

A small but significantly higher incidence of $A O M$ in males has been reported. ${ }^{13}$

\section{8- Craniofacial anomaly:}

Children with craniofacial defects or malformations are at risk for severe and recurrent $\mathrm{AOM}^{4}$ 


\section{9- Allergy:}

Children with allergy were more probable to carry Hemophilns influenzae isolates than children with no allergies. Allergies in young children have also been defined as a risk factor for otitis media because upper respiratory mucosal swelling throughout an allergic episode may cause eustachian tube dysfunction. ${ }^{14}$

To prevent the beginning of $\mathrm{AOM}$ episodes and to decrease the occurrence of recurrent AOM, several environmental control measures are recommended. Prolonged breast feeding, restrictive pacifier use and eliminating exposure to tobacco smoke have been postulated as dropping the incidence of AOM. ${ }^{15}$

The aim of this study is to evaluate the main risk factors of acute otitis media in preschool children attending ENT clinic at Al-jamhory Teaching Hospital in Mosul.

\section{PATIENTS AND METHODS}

The present study was conducted in the ENT clinic

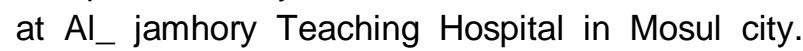
The hospital is located in the right side of Tigris River and it delivers services to many areas in Mosul city.

Case control study design has been adopted in order to achieve the objectives of the present study.

Data were collected during six months period from $1^{\text {st }}$ of Oct 2011 to the $1^{\text {st }}$ of April 2012. The present study included 150 preschool child under the age of 6 years who attend the ENT clinic at Al jamhory Teaching Hospital and diagnosed to have $\mathrm{AOM}$, and 150 control subjects in the same age group, in whom evaluation proved not to have AOM. A formal consent was obtained from parents before participation in the study. Moreover a convenient sample size was decided to be used in the study.

A questionnaire form was specially prepared in order to collect all the relevant information related to the study sample. The questionnaire form included information in regard to:

Age, gender, socioeconomic status, risk factors of acute otitis media which include day care attendance, bottle feeding during the first 6 months of life, supine bottle feeding, pacifier use in the second 6 months of life, passive tobacco smoke, craniofacial anomaly and allergy. Moreover the questionnaire contained detailed history of the disease regarding present complaint and duration and presenting symptoms. The main source of data was obtained directly from parents or relatives of the child (cases and controls) by the investigator through direct interview and filling the questionnaire form.

Clinical assessment of the cases and controls has been performed by the responsible ENT specialist. Otoscopic examination has been done for tympanic membrane for its color, translucency, light reflex, and position.

Data analysis was carried out by using Pentium four computer through the use of Microsoft Office Excel software programs.

Odds ratio was calculated by using the following equation:

$\mathrm{OR}=\frac{\boldsymbol{a} \times \boldsymbol{d}}{\boldsymbol{b} \times \boldsymbol{c}}$

95\% confidence interval $(\mathrm{Cl})$ has been calculated by using the following equation:

$95 \% \mathrm{Cl}$ of the $\mathrm{OR}=\mathrm{OR}^{1 \pm 1.96} \sqrt{X^{2}}$

Chi squared $\left(x^{2}\right)$ test was used to find the statistical association.

$P$ value $<0.05$ used as a significance statistical association.

\section{RESULTS}

This study revealed that the highest frequency of AOM was found in the age group 1-2 years [39 patients $(26 \%)]$ followed by age group 2-3 years [34 patients (22.7\%)] and the lowest frequency of AOM was observed in the age group 4-5 years [12 patients (8\%)].

The differences in the age groups 1-2 years and $2-3$ years are statistically significant $(\mathrm{p}=0.003$ and 0.005 respectively) as it shown in the Table 1.

Regarding the clinical presentation, the study showed that 99 patients $(66 \%)$ out of 150 cases complained from otalgia; 58 patients $(38.7 \%)$ complained from ear pulling; 28 patients (18.7\%) and 123 patients (82\%) complained from otorrhea and fever respectively. Moreover irritability, and vomiting were observed among 54\%, and 16\% respectively. On the other hand, vertigo was reported by only $4.7 \%$ of the patients. Table 2 .

Table 3 illustrates the association between risk factors and the occurrence of AOM. It is clear from the table that $(14 \%)$ of cases gave history of day care attendance in comparison to only $(4.7 \%)$ among controls. 
Table 1. Socio demographic characteristics and occurrence of AOM.

\begin{tabular}{|c|c|c|c|c|c|c|}
\hline \multirow{2}{*}{$\begin{array}{l}\text { Age group } \\
\text { (years) }\end{array}$} & \multicolumn{2}{|c|}{$\begin{array}{c}\text { Cases } \\
(\text { No. }=150)\end{array}$} & \multicolumn{2}{|c|}{$\begin{array}{c}\text { Controls } \\
(\text { No. }=150)\end{array}$} & \multirow[t]{2}{*}{ OR } & \multirow[t]{2}{*}{$P^{*}$-value } \\
\hline & No. & $\%$ & No. & $\%$ & & \\
\hline $0-<1$ & 20 & 13.3 & 11 & 7.3 & 1.94 & 0.088 \\
\hline $1-<2$ & 39 & 26.0 & 19 & 12.7 & 2.42 & 0.003 \\
\hline $2-<3$ & 34 & 22.7 & 16 & 10.7 & 2.45 & 0.005 \\
\hline $3-<4$ & 19 & 12.7 & 33 & 22.0 & 0.53 & 0.033 \\
\hline $4-<5$ & 12 & 8.0 & 28 & 18.7 & 0.38 & 0.007 \\
\hline $5-6$ & 26 & 17.3 & 43 & 28.6 & 0.52 & 0.020 \\
\hline \multicolumn{7}{|l|}{ Gender } \\
\hline Male & 85 & 56.7 & 82 & 54.7 & \multirow{2}{*}{1.08} & \multirow{2}{*}{0.727} \\
\hline Female & 65 & 43.3 & 68 & 45.3 & & \\
\hline \multicolumn{7}{|l|}{ Residence } \\
\hline Rural & 52 & 34.7 & 38 & 25.3 & \multirow{2}{*}{1.56} & \multirow{2}{*}{0.078} \\
\hline Urban & 98 & 65.3 & 112 & 74.7 & & \\
\hline
\end{tabular}

${ }^{*} x^{2}$-test was used.

Table 2. Frequency distribution of cases according to their clinical presentation, Mosul, 2012.

\begin{tabular}{lcc}
\hline Clinical presentation & No. & $\%$ \\
\hline Fever & 123 & 82.0 \\
\hline Otalgia & 99 & 66.0 \\
\hline Irritability & 81 & 54.0 \\
\hline Loss of appetite & 77 & 51.3 \\
\hline Ear pulling & 58 & 38.7 \\
\hline Otorrhea & 28 & 18.7 \\
Vomiting & 24 & 16.0 \\
\hline Diminished hearing & 17 & 11.3 \\
\hline Tinnitus & 8 & 5.3 \\
\hline Vertigo & 7 & 4.7 \\
\hline
\end{tabular}

With a strong association between $\mathrm{AOM}$ and day care attendance $(\mathrm{OR}=3.33,95 \% \mathrm{Cl}=1.40-7.89)$ and the difference is statistically highly significant $(\mathrm{P}=0.005)$. History of bottle feeding in the $1^{\text {st }} 6$ months of life was reported in (17.3\%) of the cases and $(6.7 \%)$ of the controls, with a strong association between the occurrence of $\mathrm{AOM}$ and bottle feeding for the $1^{\text {st }} 6$ months of life (OR=2.93, $95 \% \mathrm{Cl}=1.37-6.23)$ and the difference is statistically highly significant $(P=0.004)$. Moreover supine bottle feeding was reported by $(21.3 \%)$ of the mothers of cases compared to only $(7.3 \%)$ of the controls, also Table 2 clarifies a highly significant association between supine bottle feeding and the occurrence of $\mathrm{AOM}(\mathrm{OR}=3.42,95 \% \mathrm{Cl}=1.67-7.00)$. and the difference is statistically highly significant $(\mathrm{P}=0.001)$.
Table 3 also shows that more than three quarters of mothers of cases gave a positive history of pacifier use in the second 6 months of life, on the other hand only 9 mothers (6\%) gave positive history regarding pacifier use. There was a significant association between pacifier use in the second 6 months of life and the occurrence of AOM (OR=3.43, 95\% $\mathrm{Cl}=1.58-7.46)$ and the difference is statistically highly significant $(P=0.001)$.

Regarding parental smoking, Table 3 shows significant association with the occurrence of AOM $(\mathrm{OR}=2.46,95 \% \mathrm{Cl}=1.54-3.92)$ and the difference is statistically highly significant $(P=0.0001)$.

Table 3 shows association between baby maturity at birth and the development of $A O M$ (OR=2.28, 95\% $\mathrm{Cl}=1,26-4.12)$, the difference found to be statistically significant $(P=0.006)$.

It is clear from Table $\mathbf{3}$ that there is association between allergy and the occurrence of AOM $(\mathrm{OR}=2.29,95 \% \mathrm{Cl}=1.30-4.02)$ and the difference is statistically significant $(P=0.004)$.

Table 4 describes the parents education and occupations. It is clear from the table that $(16.1 \%)$ and $(8.1 \%)$ of the fathers and mothers of the cases had university education respectively compared to $(25 \%)$ and $(16.6 \%)$ among the control group respectively.

Moreover, the table shows that $(6.7 \%)$ and $(11.4 \%)$ of the mothers of cases and controls respectively were employed. 
Table 3. Frequency distribution of study population according to risk factors for AOM, Mosul, 2012.

\begin{tabular}{|c|c|c|c|c|c|c|c|}
\hline \multirow{3}{*}{ Risk factor } & \multirow{2}{*}{\multicolumn{2}{|c|}{$\begin{array}{c}\text { Cases } \\
\text { No. }=150\end{array}$}} & \multirow{2}{*}{\multicolumn{2}{|c|}{$\begin{array}{l}\text { Controls } \\
\text { No. }=150\end{array}$}} & \multirow{3}{*}{ OR } & \multirow{3}{*}{$95 \% \mathrm{Cl}$ of $\mathrm{OR}$} & \multirow{3}{*}{$P$ value * } \\
\hline & & & & & & & \\
\hline & No. & $\%$ & No. & $\%$ & & & \\
\hline Day care attendance & 21 & 14.00 & 7 & 4.66 & 3.33 & $1.40-7.89$ & 0.005 \\
\hline Bottle feeding & 26 & 17.33 & 10 & 6.66 & 2.93 & $1.37-6.23$ & 0.004 \\
\hline Supine bottle feeding & 32 & 21.3 & 11 & 7.33 & 3.42 & $1.67-7.00$ & 0.001 \\
\hline Pacifier use & 27 & 18.00 & 9 & 6.00 & 3.43 & $1.58-7.46$ & 0.001 \\
\hline Passive smoking & 85 & 56.66 & 52 & 34.66 & 2.46 & $1.54-3.92$ & 0.0001 \\
\hline Pre-term delivery & 39 & 26.00 & 20 & 13.33 & 2.28 & $1.26-4.12$ & 0.006 \\
\hline Craniofacial anomalies & 5 & 3.33 & 1 & 0.66 & 5.13 & $0.78-33.47$ & 0.099 \\
\hline Allergy & 44 & 29.33 & 23 & 15.33 & 2.29 & $1.30-4.02$ & 0.004 \\
\hline
\end{tabular}

Table 4. Parents education and occupation of the study population.

\begin{tabular}{|c|c|c|c|c|c|c|}
\hline \multicolumn{2}{|c|}{ Parents education } & \multicolumn{2}{|c|}{$\begin{array}{c}\text { Cases } \\
(n=150)\end{array}$} & \multicolumn{2}{|c|}{$\begin{array}{l}\text { Controls } \\
(n=150)\end{array}$} & \multirow[t]{2}{*}{$\mathbf{P}^{*}$-value } \\
\hline & & No. & $\%$ & No. & $\%$ & \\
\hline \multirow{4}{*}{ Father } & Primary & 62 & 41.3 & 58 & 38.7 & 0.637 \\
\hline & Secondary & 47 & 31.3 & 46 & 30.7 & 0.901 \\
\hline & University & 24 & 16.1 & 38 & 25.3 & 0.046 \\
\hline & Others & 17 & 11.3 & 8 & 5.3 & 0.060 \\
\hline \multirow{4}{*}{ Mother } & Primary & 92 & 61.3 & 79 & 52.7 & 0.130 \\
\hline & Secondary & 26 & 17.3 & 28 & 18.7 & 0.764 \\
\hline & University & 12 & 8.1 & 25 & 16.6 & 0.022 \\
\hline & Others & 20 & 13.3 & 18 & 12.0 & 0.728 \\
\hline \multicolumn{7}{|l|}{ Occupation } \\
\hline \multirow{3}{*}{ Father } & Employer & 35 & 23.3 & 45 & 30.0 & 0.728 \\
\hline & Retired & 7 & 4.7 & 11 & 7.3 & 0.331 \\
\hline & Earner & 108 & 72.0 & 94 & 62.7 & 0.085 \\
\hline \multirow{4}{*}{ Mother } & Employer & 10 & 6.7 & 17 & 11.4 & 0.158 \\
\hline & Retired & 0 & 0.0 & 0 & 0.0 & 1.000 \\
\hline & Non Employer & 18 & 12.0 & 23 & 15.3 & 0.401 \\
\hline & housewife & 122 & 81.3 & 110 & 73.3 & 0.098 \\
\hline
\end{tabular}

\section{DISCUSSION}

The present study used case control design in order to accomplish its objectives. The limitations of such design are selection bias, recall bias, and confounding. In this study, the maximum frequency of AOM was observed in the age group 1-2 years $(26 \%)$, the lowest frequency was at the age group 4-5 years $(8 \%)$. These values are close to the results obtained by other researchers, Alho $\mathrm{O} P$ et al, in their study of 2512 children in Finland 1991, found that children up to 24 months formed $50 \%$ of all attacks of $\mathrm{AOM}^{16}$

Serhan N, in his study of 250 cases of AOM in Baghdad city 1997, found that the percentage of children up to 24 months formed $(48,4 \%) .{ }^{17}$
In the present study males formed $(56.7 \%)$ of cases of AOM while females formed (43.3\%).This result is comparable to other studies, Serhan $\mathrm{N}$,found that male account for $(51.6 \%)$ of the patients, while female account for $(48.4 \%){ }^{17}$

Jack $L$ et al in USA 1997, found that the males consistently had higher incidence of AOM attacks than females. ${ }^{18}$

Serhan N, found otalgia (or excessive crying, head rollings, irritability) was present in (89.2\%) of patients, fever in $(62.8 \%)$, discharge in $(37.2 \%)$ and vomiting in $(29.9 \%){ }^{17}$

In the present study fever was present in (82\%) of children of AOM, Otalgia in (66\%), irritability $(54 \%)$, and vomiting in (16\%). Symptoms 
frequencies of the present study are comparable to some extend to the results of the above mentioned studies.

Alho O.P et al1991, found that the development of AOM higher in children attend daycare centers when compared with care in their homes. ${ }^{16}$

In the meta-analysis of Uhari et al in Finland 1996, the risk of AOM also increased with child care outside the home (daycare). ${ }^{19,20}$

The present study, found that there is a strong relationship between the occurrence of $\mathrm{AOM}$ and day care attendance $(P=0.005)$, which is similar to what is found in the above mentioned studies.

The present study shows that there is strong association between the occurrence of $\mathrm{AOM}$ and bottle feeding for the $1^{\text {st }}$ six months of life $(\mathrm{P}=0.004)$.

Jack L.et al, found in a study conducted in USA, 1997 a significant protective relationship between breast feeding only during the $1^{\text {st }}$ year of life. ${ }^{18}$

Serhan N, found in (121) child below two years with AOM, (69.42\%) were bottle fed, while (30.58\%) were breast fed. ${ }^{17}$

A meta analysis conducted by Uhari et al, concluded that breast feeding in the first 3 months of life reduce the risk of AOM by $(13 \%) .{ }^{19}$

The present study showed that the supine bottle feeding was significantly associated with the occurrence of AOM. (95\% $\mathrm{Cl}=1.67-7.00, \mathrm{P}=0,001)$. This result was similar to that found by other studies.

Jose $F$ et al (2006), found that one of the mechanisms involved in the association between bottle feeding and $\mathrm{OM}$ is "positional OM", according to which children bottle fed in an unsuitable position (lying down) are great risk for AOM, as shown in a cohort with (698) children followed up from birth to two years of age demonstrated that the supine bottle feeding position was associated with earlier onset of AOM. ${ }^{21}$ This might be due to aspiration of milk during supine feeding.

The present study, demonstrates a significant association between occurrence of $\mathrm{AOM}$ and the use of pacifier in the $2^{\text {nd }} 6$ months of life. $(95 \% \mathrm{Cl}=1.58-7.46, \mathrm{P}=0.001)$.

Niemela et al in his study in Finland, demonstrated that those used pacifiers had a greater risk of presenting with four or more episodes of AOM than those who did not use them. ${ }^{22,23}$

Uhari et al, found that the use of a pacifier increase the risk for AOM by (24\%). ${ }^{19}$ Warren et al (2001) in his study in USA, demonstrated that pacifier sucking was significantly associated with AOM from the 6th to the 9th months and presented a strong trend towards statistical significant in the period from 9-12 months. ${ }^{24}$ This is probably due to eustachian tube dysfunction associated with pacifier sucking.

The present study, parental tobacco smoking significantly associated with the occurrence of AOM. $(95 \% \mathrm{Cl}=1.54-3.92, \mathrm{P}=0.0001)$, this result found to be similar to many other studies which are conducted in Iraq and other countries. Serhan N, reported that children of smoking families had higher incidence of AOM (53.2\%) compared to $(46.8 \%)$ in those of non-smoking families. ${ }^{17,25}$ Uhari et al, found that the parental smoking increased the risk of AOM. ${ }^{19}$

On the other hand Jose F.et al (2006), concluded that passive smoking does not increase the chance of non-recurrent $A O M$, with regard to recurrent $A O M$, passive smoking was classified as a probable risk factor. ${ }^{21}$

The present study, observed that there is significant association between pre maturity and the occurrence of $A O M$, this result found to be similar to the result of Becken et al (2001), in his study in USA, found that very preterm birth $(<33$ weeks of gestation ) and very low birth $(<1500 \mathrm{~g})$ increase risk of $\mathrm{AOM}^{26}$ This is probably due to altered immunity in this group.

A study conducted by Boston $\mathrm{M}$ et al (2003) in USA, demonstrated that the presence of craniofacial anomaly increased the chance of the child requiring multiple interventions for ventilation tube placement, so higher incidence of AOM occurred among children with un corrected cleft palate than in normal children, and when the cleft is corrected, AOM recurrence is reduced. ${ }^{27}$

Nevertheless the present study demonstrate no association between craniofacial anomaly and the occurrence of $A O M$, this result most probably attributed to small sample size and the little number of cases of craniofacial anomalies which are included in the study population.

The present study found there is significant association between allergy and the occurrence of 
AOM $(95 \% \mathrm{Cl}=1.30-4.02, \quad \mathrm{P}=0.004)$, this result found to be comparable with another study conducted by Bernstein JM (2002), New York, USA, found that atopic Eustachian tube obstruction may eventually lead to AOM by gradual accumulation of viruses and bacteria in ear effusion. ${ }^{28,29}$

In the other hand Jose $\mathrm{F}$ et al (2006), found that although there is epidemiologic, mechanical and therapeutic evidence showing that allergic rhinitis contributes to the pathogenesis of AOM it needs further study before more definitive conclusions can be drawn. ${ }^{21}$

\section{CONCLUSIONS}

From the results of the present study the following conclusions can be obtained:

The highest frequency of acute otitis media occurred in the age group 1-2 years. The significant risk factors for AOM were day care attendance, bottle feeding for the $1^{\text {st }} 6$ months of life, supine bottle feeding, pacifier use in the second 6 months of life, parental tobacco smoking, preterm baby, and allergy.

\section{RECOMMENDATIONS}

1. Supplementary studies on probable measures to prevent AOM through the reduction of risk factors are needed.

2. The main health care priorities in distant communities be supposed to: carry strategies that decrease the transmission of bacterial infections to infants and toddlers, support sensible vaccination, counsel on effective communication strategies for hearing impaired offspring, provide recurrent and precise assessment of middle ear disease in the first 18 months of life.

\section{REFERENCES}

1. John M Graham, Glenis K Scadding. Pediatric ENT $2^{\text {nd }}$ ed. ISBN:978-3-540-3308-7. Springer Berlin Heidelberg New York;2007 :31-76.

2. Teele DW, Klein JO, Chase C, Menyuk P, Rosner BA, the Greater Boston Otitis Media Study Group. Otitis media in infancy and intellectual ability, school achievement, speech, and language at age 7 years. $J$ Infect Dis 1990; 162:685-94.

3. Charles C, James S, Robert H Rakel: Text book of Family Medicine. $7^{\text {th }}$ ed. New York: Saunders; 2011:62679.
4. Robert $E$ Rakel. Essential family medicine: fundamentals \& case study. $3^{\text {rd }}$ ed. Philadelphia, Pennsylvania: Elsevier; 2007.p.234-67

5. Marianne M Green, Jennifer A Bierman, JAMES j. Foody, Russell G. Robertson, Gary J. Martin. Prymary care mentor. Philadelphia, PA 19103, United States of America; 2009.

6. American Academy of Pediatrics Subcommittee on Management of Acute Otitis Media. Diagnosis and management of acute otitis media. Pediatrics 2004; 113(5):1451-65.

7. Bennett KE, Haggard MP Accumulation of factors influencing children's middle ear disease: risk factor modeling on a large population cohort. $J$ Epidemiol Community Health 1998; 52: 786-793.

8. Duffy LC, Faden $H$, Wasielewski $R$, et al. Exclusive breastfeeding protects against bacterial colonization and day care exposure to otitis media. Pediatrics 1997; 100:E7.

9. Mumtaz $Y$, Habib F, Jahangeer A, Habib A. Determinations of Acute Otitis Media in infant. JDUHS 2009; 3(1):10-15.

10. Niemelä M, Pihakari O, Pokka T, Uhari M. Pacifier as a risk factor for acute otitis media: a randomized, controlled trial of parental counseling. Pediatrics 2000; 106: 483-488.

11. Jacoby $P$, Coates $H$, Arumugaswamy $A$, et al. The effect of passive smoking on the risk of otitis media in Aboriginal and non-Aboriginal children in the KalgoorlieBoulder region of Western Australia. Med J Aust 2008; 188: 599-603.

12. Engel J, Anteunis L, Volovics A, et al. Prevalence rates of otitis media with effusion from 0 to 2 years of age: healthy-born versus high-risk-born infants. Int $\mathrm{J}$ Pediatr Otorhinolaryngol 1999; 47: 243-251.

13. Zakzouk S M, Hajjaj M F. Epidemiology of Chronic suppurative otitis media among Saudi children a comparative study of 2 decades. Int $\mathrm{J}$ Paediatr Otorhinolarygol 2002;62:215-8.

14. Scottish Intercollegiate Guidelines Network. Diagnosis and management of childhood otitis media in primary care. SIGN guideline No. 66. February 2003.

15. Williams RL, Chalmers TC, Stange KC, Chalmers FT, Bowlin SJ Use of antibiotics in preventing recurrent otitis media and in treating otitis media with effusion: a meta-analytic attempt to resolve the brouhaha. JAMA 1993; 270:1344-1351.

16. Alho OP, Koivu M, Sorri $M$, Rantakallio P. The occurrence of acute otitis media in infants. Int $\mathrm{J}$ Pediatr Otorhinolaryngol.1991; 21(1):7-14.

17. Nasir Hindi Serhan. Acute otitis media in infant and children. Al_Nahrain University, Medical Collag; 1997; 4:34-35

18. Jack $L$ Paradise, Howard E Rockette, D. Kathleen Colborn, Beverly S. Bernard, Clyde G. Smith, Marcia Kurs-Lasky and Janine E. Janosky. Otitis Media in 2253 Pittsburgh-Area Infants: Prevalence and Risk Factors During the First Two Years of Life. Pediatrics J 1997; 99:318.

19. Uhari M, Mantysaari K, Niemela M. A meta-analytic review of the risk factors for acute otitis media. Clin Infect Dis. 1996; 22: 1079-1083.

20. Mottonen $M$, Uhari M. Absences for sickness among children in day care. Acta Paediatr 1992; 81: 929-32. 
21. José Faibes Lubianca Neto, Lucas Hemb, Daniela Brunelli e Silva. Systematic literature review of modifiable risk factors for recurrent acute otitis media in childhood J Pediatr (Rio J) 2006; 82(2):87-96.

22. Niemela $M$, Uhari $M$, Hannuksela $A$. Pacifiers and dental structure as risk factors for otitis media. Int $\mathrm{J}$ Pediatr Otorhinolaryngol. 1994; 29:121-7.

23. Larsson E. Dummy- and finger-sucking habits in 4year-olds. Swed Dent J 1975; 68: 219-24.

24. Warren JJ, Levy SM, Kirchner HL, Nowak AJ, Bergus GR. Pacifier use and the occurrence of otitis media in the first yearof life. Pediatr Dent 2001;23:103-7. 25. Ilicali OC, Keles N, Deer K, Asum OF, Guldiken Y. Evaluation of the effect of passive smoking on otitis media in children by an objective method: urinary cotinine analysis. Laryngoscope $2001 ; 11: 163-7$.
26. Becken ET, Daly KA, Lindgren BR, Meland $M H$, Giebink GS. Low cord blood pneumococcal antibody concentrations predict more episodes of otitis media. Arch Otolaryngol Head Neck Surg 2001; 127:517-522.

27. Boston M, McCook J, Burke B, Derkay C. Incidence of and risk factors for additional tympanostomy tube insertion in children. Arch Otolaryngol Head Neck Surg 2003; 129:293-6.

28. Bernstein JM. Immunologic aspects of otitis media. Curr Allergy Asthma Rep 2002; 2 (4): 309-15.

29. Kraemer JK, Richardson MA, Weis NS, Furukawa CT, Shapiro GG, Pierson WE. Risk factors for persistent middle-ear effusions. JAMA 1983; 249:1022-5. 